\title{
Non-disclosure in insurar
law: a more principled approach
}

\author{
by Ravi Aswani
}

The author puts forward an option for reform that the English and Scottish Law Commissions might like to consider in their future consultation paper on insurance contract law.

$\mathrm{N}$ early 100 years ago Fletcher Moulton LJ stated "I am satisfied that few of those who insure have any idea how completely they leave themselves in the hands of the insurers should the latter wish to dispute the policy when it falls in" in Joel $v$ Law Union and Crown Insurance Company [1908] 2 KB 863 at p885. His criticism has been repeated on many occasions by others, including for example Staughton LJ who recently stated as follows in Kausar v Eagle Star Insurance Co Ltd [2000] Lloyd's Rep IR 154 at p157:

"Avoidance for non disclosure is a drastic remedy. It enables the insurer to disclaim liability after, and not before, he has discovered that the risk turns out to be a bad one; it leaves the insured without the protection which he thought he had contracted and paid for. Of course, there are occasions where a dishonest insured meets his just deserts if his insurance is avoided; and the insurer is justly relieved of liability. I do not say that non-disclosure operates only in cases of dishonesty. But I do consider that there should be some restraint in the operation of the doctrine. Avoidance for honest non-disclosure should be confined to plain cases."

The general complaint is that the insurer who wishes to avoid a policy for non-disclosure is in a very strong position given his right to treat the policy as void from the outset. This article examines the legal position and puts forward a suggestion for reform that might lead to a more balanced and fair position between insurer and insured.

\section{THE PRESENT POSITION IN LAW}

Judicial expressions such as the two set out above of concern relating to the onerous duties of disclosure imposed on proposers of insurance policies and to the draconian consequences of falling short of the requirements of those duties are not hard to find. The broad topic of non-disclosure in insurance law has already been considered by distinguished lawyers in the context of reform (namely by committees chaired by Devlin J and by
Kerr J) but their recommendations have not been implemented.

The following two settled principles apply in this context. Firstly, the proposer is under a duty at the time of making (or renewing) a policy to disclose to the insurer all material information affecting the risk to be insured. Secondly, the (usual) remedy for non-disclosure is rescission ab initio of the policy at the behest of the insurer. Any doubt that there might have been that rescission $a b$ initio of an insurance policy for non-disclosure operated by act of the party rather than order of the Court was firmly removed by the Court of Appeal in Brotherton v Aseguradora Colseguros SA (No 2) [2003] Lloyd's Rep IR 746 (see judgment of Mance LJ at par 27). Thus, the insurer does not need to obtain an order of the Court before being entitled to treat the policy as void - all he needs to do is to tell the insured that the policy is being avoided for nondisclosure.

The scope of the duty can be problematic in practice. Materiality is tested by reference to the prudent insurer. Section 18(2) of the Marine Insurance Act 1906 states that "every circumstance is material which would influence the judgment of a prudent insurer in fixing the premium or determining whether he will take the risk." In Lambert v $\mathrm{Co}_{-}$ operative Insurance Society Limited [1975] 2 Lloyd's Rep 485 Mackenna J giving the leading judgment in the Court of Appeal confirmed that the same test of materiality applied to non-marine insurance (pp488-89). In theory at least, this is an objective test based on what would influence the judgment of the prudent insurer at the time of placing. The proposer is therefore required to disclose matters which he might perfectly genuinely believe would not be of interest to insurers, the problem being particularly acute if the proposer is insuring in a private capacity and has little idea of what the prudent insurer might consider material. This problem is neatly illustrated by the following passage from the judgment of Forbes J in Reynolds v Phoenix Assurance Co Ltd [1978] 2 Lloyd's Rep 440 at p457, col2: 
"Now to adopt the objective insurer test and reject the objective proposer is to pose this problem; it follows that any proposer is bound to disclose that which no reasonable proposer would regard as material. As a difficulty this was referred to both by the Law Reform Committee and by the Court of Appeal in Lambert's case. In the course of the trial I wondered whether the problem was rather a theoretical one than a practical one and the answer to the problem was that no reasonable insurer would require disclosure unless it was of something which a reasonable proposer would in fact realise was material. I accordingly canvassed this possibility with some of the insurance witnesses. In the event only one of them was prepared to accept this suggestion; the others to whom I put the point rejected it."

However, good faith on the part of the proposer in not disclosing matters which the prudent insurer would consider material, and the fact that the reasonable proposer would not appreciate materiality, are not valid defences.

Further, the degree of materiality required assists insurers at the expense of insureds. In Pan Atlantic Ins Co Ltd v Pine Top Ins Co Ltd [1995] 1 AC 501 Lord Mustill (with whom Lord Goff and Lord Slynn agreed) made two points. Firstly, the relevant common law principles were mirrored in the provisions of the Marine Insurance Act 1906. Secondly, the words "influence the judgment of a prudent underwriter" in s18(2) of that Act did not require decisive influence, and had such a requirement been intended the word "influence" would have been qualified in the Act: an influence, even if not decisive, was sufficient - p531. The duty extended to "all matters which would have been taken into account by the underwriter when assessing the risk" p538. Thus, "a circumstance may be material even though a full and accurate disclosure of it would not in itself have had a decisive effect on the prudent underwriter's decision whether to accept the risk and if so at what premium" p550.

Thus the proposer is obliged to disclose matters which even if disclosed might have led to the insurer agreeing to insure on identical terms, though some alleviation is provided by the inducement requirement considered below.

Where an insured is found to have committed material non-disclosure, the insurer has the right to avoid the policy if he so wishes. The effect of this is rescission ab initio of the policy, and though the insured will be refunded his premium, he cannot compel the insurer to continue the policy (even on different terms). A particularly harsh example of this is provided by the facts of Mackay $v$ London General Insurance Company Ltd (1935) 51 Ll L Rep 201. To the question of "Has any office or underwriter refused, cancelled or declined to accept or renew such insurance, or required an increased premium or special condition?" the insured answered "No", but in fact when 18 he had obtained motorcycle insurance subject to a $£ 210$ s excess.
To the question of "Have you or your driver ever been convicted or had a motor licence indorsed?" he answered "No" when in fact he had been fined 10s several years before because a nut on the brakes of his motorcycle had become loose. Swift J expressed in poignant terms his considerable regret in confirming the insurer's right to avoid the policy (at p202).

However, since Pan Atlantic, it has been clear that "if the misrepresentation or non-disclosure of a material fact did not in fact induce the making of the contract (in the sense in which that expression is used in the general law of misrepresentation) the underwriter is not entitled to rely on it as a ground for avoiding the contract" - per Lord Mustill at p550. Thus the insurer must show that he was induced to write the insurance policy as a result of the nondisclosure. Whilst this seems to offer a sort of safeguard for the insured, unfortunately the insurer will seldom have significant difficulty with this point. Firstly, as pointed out by Halsbury, there may be some cases where "materiality is so obvious" (Halsbury's Laws of England (4th edition), volume 31, para1067). But even where this is not the case, the insurer will in the majority of cases be able to provide evidence of inducement either from the underwriter in question, or possibly evidence of market practice from which inducement can be inferred, either of which an insured would find difficult to rebut.

As can be seen then, the position in law relating to an insurer's right to avoid for non-disclosure does appear to be stacked somewhat disproportionately in favour of the insurer at the expense of the insured.

\section{PREVIOUS RECOMMENDATIONS FOR REFORM}

Non-disclosure in insurance law was considered in the Fifth Report of the Law Reform Committee (under the chairmanship of Devlin J) (1957) Cmnd 62 and (following a consultation paper) in a Report entitled Insurance Law: Non-Disclosure and Breaches of Warranty (under the chairmanship of Kerr J) (1980) Cmnd 8064. Additionally, in 1979 the European Commission proposed a Directive dealing with, inter alia, questions of disclosure in insurance law: the Kerr Committee rejected its implementation; and it does not appear that it will be enacted (at least in its present form).

So far as presently material, the Kerr Committee stated as follows. Firstly, the "proportionality" principle embodied in the draft EC Directive (that the insured should pay out only a proportion of the claim, determined by the ratio of the premium charged and the premium that would have been charged but for the non-disclosure) was problematic (paras $4.5-4.17$ ). This was largely because the insurer could have reacted to the undisclosed facts in ways other than increasing the premium (para 4.5) and in particular, may have refused to insure the risk at all (para 4.6). Secondly, "The total abolition of any duty of 
disclosure would be undesirable and impractical" (para 4.32), even for consumers (para 4.35 et seq). Even an attenuation of the duty in relation to customers would "lead to anomalous results in practice" (para 4.42). Thirdly, the duty of disclosure should extend to facts that would influence a prudent insurer decisively (cf Pan Atlantic), that the insured had actual or constructive knowledge of, and that a reasonable insured in the position of the insured would have disclosed (paras $4.47-4.53$ ).

Finally, as regards any restricting of insurers' rights of avoidance, a "nexus test", requiring a connection between the non-disclosure complained of and the loss suffered, was misconceived, primarily because where there was no "nexus" insurers would be bound by contracts whose terms would have been different but for the non-disclosure (paras $4.89-4.97$ ). Whilst a judicial discretion to reduce the insured's entitlement might give flexibility, it would lead to uncertainty and excessive litigation, and ultimately would do more harm than good (paras 4.98 - 4.108).

Whilst the approach of the Kerr Committee is generally sound, it is respectfully submitted that it is particularly problematic in one respect. The committee recommended that the duty to disclose should only extend to matters which a reasonable insured in the position of the insured would have disclosed. Yet in a great many cases, even a reasonable insured would not have disclosed matters that an insurer would have considered very pertinent, perhaps so pertinent that the insurer would have refused cover. This is the very problem that Forbes $\mathrm{J}$ alluded to in Reynolds $\mathrm{V}$ Phoenix Assurance Co Ltd in the passage set out above. The approach of the Kerr Committee risks, it is submitted, placing the law of non-disclosure too much in favour of the insured, because the insurer would in many cases be bound to terms other than those he would have agreed but for the non-disclosure.

This point brings into sharp focus the nub of the present problem - the tension between holding parties to be bound by freely entered into agreements, and providing a remedy where consent to the agreement can be said to be vitiated in some way. The insurer is either bound to terms less onerous on the insured than would have been the case but for the non-disclosure (Kerr Committee approach), or the insurer can escape from terms freely entered into by reason of a trivial non-disclosure by the insured (present law).

The present writer certainly agrees with the Kerr Committee that the principle of non-disclosure performs a valuable commercial function and should not be abolished. A more satisfactory answer than the all or nothing effect of both the present law and the Kerr Committee recommendation may well lie elsewhere. A more principled approach would be to focus not on holding parties to be bound to freely entered into agreements and not bound where consent can be said to be vitiated, but rather holding them to be bound by the terms that would have been agreed but for the non-disclosure.

\section{REFORM: THE STATUTORY ANTI-AVOIDANCE CLAUSE}

The validity of the anti-avoidance clause in insurance law is now beyond doubt. In Toomey $v$ Eagle Star Insurance Co Ltd (No 2) [1995] 2 Lloyd's Rep 88, Colman J accepted, in the light of previous authority, that "it is indeed possible to write a clause into a contract which does in fact exclude the right to rescind the contract for material misrepresentation or material non-disclosure." The conceptual difficulty relied upon by the insurer in that case was that nondisclosure would permit rescission of the very contract in which the clause restricting the right to rescind appeared, so it would be a bootstraps argument for the insured to attempt to rely upon such a clause. However, Colman J, noting that there was authority on this point, took the contrary view.

The insurer's right to avoid is enshrined in section 17 of the Marine Insurance Act 1906. It is the proposal of the present writer that the solution to the problem considered above would be for a statute to be enacted implying a suitable anti-avoidance clause into all contracts of insurance. This would probably require at least substantial amendment, if not repeal of section 17. Some would say that such a step would be long overdue, and any new insurance legislation effecting the proposed reform could easily deal with this.

At first glance, it might appear that such a proposal would have an effect as rigid as the Kerr Committee recommendation. However, the following features are also proposed. First, the insurer should be able to avoid the policy where he can prove either that the insured has committed fraud or that he would not have entered into a policy on any terms if the undisclosed facts had been disclosed. The justification for the former is self-evident. As for the latter, it is suggested that it would be wrong in principle to compel insurers to abide by policies that they can prove they would not have entered into on any terms. Second, if the insurer can prove that he would have entered the policy on different terms, such as an increased premium, a higher excess or deductible, or different terms of cover, then the policy should be retrospectively varied to reflect those terms.

It is acknowledged that the second of the above features might give rise to practical difficulties in evidential terms. A higher premium or excess is relatively easy retrospectively to deal with, but it may be that the insurer can prove, for example, that he would have reinsured a proportion of the risk. However, the above proposal has the advantage that if the insurer can prove that he would have reinsured, say, half the risk, then the insured could still compel the insurer in effect to pay out half the claim. When compared to the present all or nothing approach, 
this is surely preferable, and moreover such an approach would bring home to proposers the continuing need to make full disclosure of material facts notwithstanding the statutory anti-avoidance clause. At the same time, this approach would have the effect of holding the parties to the bargain that they would have made but for the nondisclosure (in particular, it would stop insurers rejecting largely meritorious claims for the most trivial of nondisclosures), which as a matter of principle is, it is submitted, sound.

This approach would be more sophisticated than the proportionality approach criticised by the Kerr Committee, and preferable to that approach: it should be remembered that the proportionality approach focuses simply on the increased premium that the insured would hypothetically have charged (or perhaps the increased excess that would have been imposed) had the nondisclosure not occurred (see also for instance Insurance Law Update, Roger Kay, (2005) 26 BLR (6) 153 at p154 suggesting that the insured should be allowed to recover "with an adjustment to reflect the premium that should have been paid to reflect the increased risk").

The suggested approach allows the insurer the opportunity to prove to the court (and the burden should be on the insurer) not only that he would not have entered into the insurance on any terms at all, but alternatively that he would have required a higher excess or would have imposed other special conditions (which may have led to the event which occurred giving rise to the claim not being within the scope of the cover), as well as requiring a higher premium. The crucial point is that the insurer might, by proving that he would have imposed other special conditions or insured on different terms, be able to avoid paying out on a particular claim (which would not be covered under the different terms), but would not be able to avoid the insurance policy as a whole, thereby preserving the right of the insured to put forward other claims and succeed where the non-disclosure has made no difference because those claims would have been covered under either set of terms. The insurer may well find it straightforward to prove that he would have insured with a higher premium, and the insured will find it difficult to adduce evidence in rebuttal, but the insured will surely prefer this to the policy being avoided ab initio. The Court would no doubt be vigilant in carefully scrutinizing claims that the insurer would have insured on different terms which would have happened to exclude the loss claimed on a particular occasion, and this should provide a safeguard against insurers speculatively taking this point as a matter of routine.

Although the suggested approach is admittedly a little artificial, it is nevertheless a fair and principled balance between all or nothing approaches which arguably are more artificial. The starting point should always be that (fraud aside) the insurer is by statute prohibited from avoiding the policy ab initio by virtue of a statutory implied term to that effect which cannot be contracted out of.

This proposal is similar to the 25 th recommendation in the Australian Law Reform Commission's Review of the Marine Insurance Act 1909 (Report 92 of April 2001) which would preserve the right to avoid for fraudulent non-disclosure (with no return of premium) and insert considerations of proportion in other cases. However, that recommendation still would not deal with matters other than the financial ones of different premium, deductible or excess that would have been imposed, such as different conditions of cover. The proposal suggested is more flexible that this, as set out above. It is acknowledged that reform along the lines suggested in this article would no doubt lead to a modest increase in premiums across the board, but this is surely preferable to the present state of affairs which enables insurers to avoid policies for the most trivial and innocent of non-disclosures.

A word should perhaps be said about the need for legislative reform at all. So far as private insurance is concerned, the Statement on General Insurance Practice ("the Statement") and the Statement on Long-Term Insurance Practice issued by the Association of British Insurers and Lloyd's constitute a voluntary code governing relations between insurers and insureds. Until very recently, these statements lacked legal effect, but the former has in some part now been given regulatory force by the Insurance Conduct of Business Rules ("the Rules") made by the Financial Services Authority pursuant to its powers under the Financial Services and Markets Act 2000. The Rules came into force in January 2005. The Statement and now the Rules provide, so far as presently material, that insurers should not insist upon enforcement of their strict legal rights against consumers in cases of inter alia non-disclosure (see in particular Rule 7.3.6).

It is submitted that the Kerr Committee's opinion (of what was then the Statement) is apt. As well as stating, as set out above, that there should in principle be no difference in approach to "consumer" and "nonconsumer" insurance, the Kerr Committee stated that "the Statements of Insurance Practice are themselves evidence that the law is unsatisfactory and needs to be changed... [they] lack the force of law so that an insured would have no legal remedy if an insurer fails to act in accordance with them" (para 3.28). A similar view was taken by the learned editors of MacGillivray on Insurance Law (9th edition, 1997) at paragraph 17.100 - "we do not regard these statements of self-regulatory practice as a substitute for reform of the law". The 10th edition of that same work (2003) states the same at paragraph 17.104, though it has not been updated to take account of the coming into force of the Rules in January 2005

Although now the Statement and the Rule have the force of law, the cogent criticism remains that there is no reason in principle to limit the insurer's right to avoid for non- 
disclosure only to the consumer insurance field (albeit that the effects will no doubt be felt mostly harshly by such insureds). As early as 1975 Lawton LJ in Lambert $v$ Cooperative Insurance Society stated: "Such injustices as there are must now be dealt with by Parliament, if they are to be got rid of at all.” [1975] 2 Lloyd's Rep 485 at p492, quoted with approval by the Kerr Committee (paragraph 3.28). The Rules go some way towards addressing the problem, but wholesale reform along the lines suggested in this article would, it is respectfully suggested, be a more satisfactory way of approaching the problem.

Reform is, it would appear, now on the horizon. In January 2006 the Law Commission and the Scottish Law Commission published a Joint Scoping Paper inviting suggestions as to which areas (in addition to non-disclosure and breach of warranty) should be considered in a consultation paper on insurance contract law. At paragraph 1.9 the Scoping Paper states as follows: "We do not accept the arguments of one consultee who suggested that extensive rules from the Financial Services Authority ("FSA") and the mechanisms for change already in place were an adequate substitute for review of the law." At paragraphs 1.14 to 1.25 the Scoping Paper convincingly sets out why certain points made by those against reform are weak points, and at paragraph A4 of Appendix A the Scoping Paper sets out some of the concerns the Law Commissions have about the present law of nondisclosure. At paragraph 1.6 the Scoping Paper refers to the influence of the Insurance Contract Law Reform
Report of the British Insurance Law Association (September 2002) in the decision to consider reform in this area. That report stated at paragraph 11 as follows:

"We agree whole-heartedly with the Commission that Statements of Practice, particularly limited to those insuring in their private capacity, are not sufficient to protect insureds. Nor do we think that the fact that the Ombudsman is bound to act in accordance with what is fair and reasonable and therefore does not always apply the strict letter of the law, removes the need for law reform. Many disputes are not settled by that route. The appropriate course is to remove unfairness in the law, not simply to alleviate the unfairness."

At paragraph 17.3.4 the BILA recommended a solution "on the lines of Recommendation 25 of the ALRC", but that recommendation is based on the principle of proportionality, which as set out above is limited to financial considerations. It is thus clear that there is a case for law reform as regards non-disclosure in insurance law, and that at long last progress might shortly be made in this area. It is suggested that the option set out in this article, wider than the proportionality principle which many have advocated before, is an option that the Law Commissions might like to consider in their consultation paper to be produced in due course.

Ravi Aswani

Barrister, Stone Chambers, London 